\title{
Mesophotic depth biogenic accumulations ("biogenic mounds") offshore the Maltese Islands, central Mediterranean Sea
}

Bialik, Or. M. ${ }^{1 *}$, Varzi, Andrea Giulia ${ }^{2}$, Duran Gallego, Ruth ${ }^{1}$, Le Bas, Timothy ${ }^{3}$, Gauci, Adam ${ }^{1}$, Savini, Alessandra ${ }^{2}$, Micallef, Aaron ${ }^{1}$

\footnotetext{
${ }^{1 .}$ Department of Geosciences, University of Malta, Msida, MSD 2080, Malta

2. Department of Earth and Environmental Sciences, University of Milano-Bicocca, Piazza della Scienza 4, 20126, Milano, Italy

${ }^{3 .}$ National Oceanography Centre, Southampton, SO14 3ZH, United Kingdom

*Correspondence: or.bialik@um.edu.mt
}

This manuscript is an EarthArXiv preprint and has been submitted for possible publication in Frontiers in Marine Sciences. Please note that this has not been peer-reviewed before and is currently undergoing peer-review for the first time. Subsequent versions of this manuscriptmay will have slightly different content.

Please feel free to contact the authors; we welcome any feedback. 


\title{
Mesophotic depth biogenic accumulations ("biogenic mounds") offshore the Maltese Islands, central Mediterranean Sea
}

\author{
Bialik, Or. M. ${ }^{1 *}$, Varzi, Andrea Giulia ${ }^{2}$, Duran Gallego, Ruth ${ }^{1}$, Le Bas, Timothy ${ }^{3}$, Gauci, Adam ${ }^{1}$, \\ Savini, Alessandra ${ }^{2}$, Micallef, Aaron ${ }^{1}$ \\ ${ }^{1 .}$ Department of Geosciences, University of Malta, Msida, MSD 2080, Malta \\ 2. Department of Earth and Environmental Sciences, University of Milano-Bicocca, Piazza della Scienza 4, 20126, Milano, Italy \\ ${ }^{3 .}$ National Oceanography Centre, Southampton, SO14 3ZH, United Kingdom \\ *Correspondence: or.bialik@um.edu.mt
}

\begin{abstract}
The mesophotic domain is a poorly explored part of the oceans, notably in the Mediterranean Sea. Benthic communities in these depths are not well documented and as such are under higher risk from anthropogenic impacts. Hard substrate habitats in this depth window are not common and are a key ecotope. The Malta Plateau in the central Mediterranean, which is characterised by low sedimentation rates, offers a potentially unexplored domain for these features. Bathymetric and backscatter data offshore of the eastern coast of the island of Malta were used to characterise the benthic habitats. $>1700$ small structures were identified in mesophotic depth and verified by dives to be biogenic mounds. These mounds extend from several meters to tens of meters in diameter and occur in two main depth windows 40 to $83 \mathrm{mbpsl}$ and 83 to $120 \mathrm{mbpsl}$, each formed probably in a different stage along the last glacial cycle. The mounds are composed of interlocking bioconstruction by encrusting organisms and are colonised by sponges and various cold water corals (most of which are protected). This unique and important habitat is currently under grave threat by human activity, most immediately by trawling activity.
\end{abstract}

Keywords: Biogenic mounds, Reefs, Natural heritage, Coralline algae, Trawl marks, Seafloor mapping, Malta Plateau 


\section{Running Title}

\section{Introduction}

\subsection{Biogenic mounds}

The term "mound" is commonly used in literature to indicate biogenic-mediated features forming submerged positive reliefs (from a few to hundreds of metres in height), composed of a variety of dominant organisms capable of trapping or baffling fine sediments (e.g. cold-water corals, bryozoans, polychaetes). Mounds occur in a variably-composed sedimentary matrix, and display rounded, semicircular, ellipsoidal or elongated planforms (Riding, 2002; Henriet et al., 2014). The terminology used to describe mound-like biogenic submarine landforms in cold water is inconsistent across literature. Terms like "patch reefs", "pinnacle reefs", "reef mounds", "carbonate mounds" and others are frequently used to refer to "mounded" biconstructions developed in temperate seas (Greene et al., 1999; Wood, 2001; Riding, 2002; Bare et al., 2010). Comparative analysis of these features, which have only recently been reported in literature thanks to advancements in underwater exploration techniques, is critical but difficult. The different origin, composition and structure of mounds is often missing in the numerous examples reported in literature. In order to avoid adding confusion to the terminologies already in use, and to document the environmental relevance that biogenic landforms seem to hold in mesophotic depths, we use here the general terms "biogenic mound" to describe the observations or "mounded bioconstruction" when referring to the growth process.
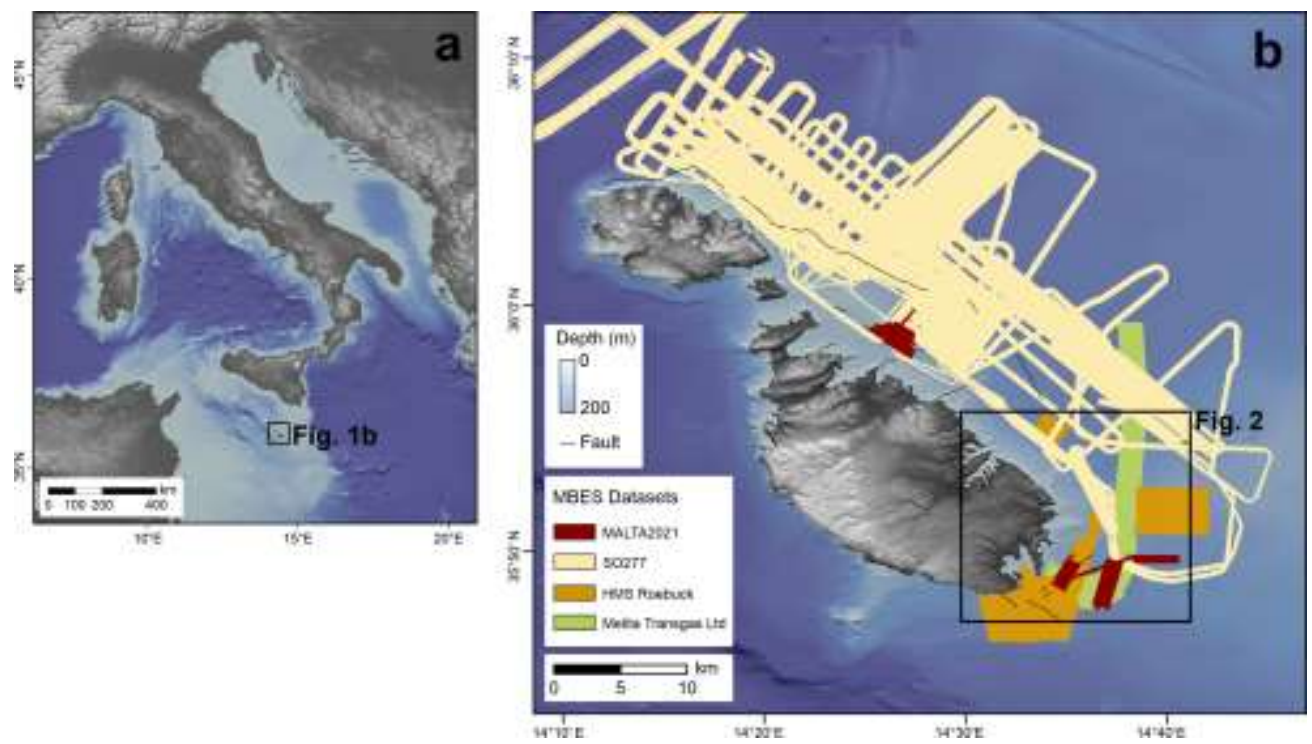

Figure 1: Location map. (a) Overview map (upper left, ETOPO) shows the location of Malta, (b) Available bathymetric data from the seafloor surrounding the Maltese Island, research area for this study is marked with a red box. '(C) Crown Copyright and/or database rights. Reproduced by permission of The Keeper of Public Records and the UK Hydrographic Office (www.GOV.uk/UKHO).'

Biogenic mounds have been detected all over the world, although a precise description of their distribution, origin and morphology is often overlooked. Indeed, the study of such bioconstructions 
has benefitted from the increased availability of seafloor acoustic maps and Remotely Operated Vehicle (ROV) imagery. In the literature, cold-water coral carbonate mounds are the most welldocumented structures. Hovland et al. (1994) were some of the first to describe sub-photic carbonate build-ups - referred to "seabed mounds" - offshore western Ireland. Since then, several studies have revealed thousands of deep-water carbonate mounds. Biogenic mounds have developed in a wide depth range, from coastal areas to deeper environments, and they can be formed by a variety of organisms. The dimensions and shapes of mounds may vary a lot, with heights ranging from a few metres to $>300 \mathrm{~m}$, and lateral extensions of up to tens of kilometers (Ramos et al., 2017; Wienberg et al., 2018; Hebbeln et al., 2019). The bioconstructions are normally grouped into provinces, which may comprise tens to hundreds of individual mounds (Hebbeln et al., 2014; Glogowski et al., 2015). These morphologies have been observed and documented along the Atlantic margins (from northern Norway to Mauritania and from Brazil to Canada) and the Mediterranean Sea (Lo Iacono et al., 2008; White and Dorschel, 2010; Corbera et al., 2019; Hebbeln et al., 2019). The investigation of such zones is essential to describe submarine landscapes, although most of the time they are largely neglected within classification schemes (Greene et al., 1999; Hebbeln et al., 2019).

There is no consensus in the literature regarding the timing and mechanism of mounded bioconstruction formation. Mounds have been related to hydrocarbon seepage (Wheeler et al., 2007; Foubert and Henriet, 2009) or autogenic processes stimulated by high current speeds and food supply (Mienis et al., 2007; White, 2007; Foubert and Henriet, 2009). Some authors (Abbey et al., 2013) ascribed their formation to reefs developed during short-lived periods of slow sea-level rise during the Holocene transgression and subsequent drowning that halted their growth. Other authors (Locker et al., 2016) ascribe their origin to reefs developed during periods of low sea-level amplitude in the last glacial cycles that were terminated due to a combination of emersion and drowning during the glacial maximum and subsequent transgression. Both models are based on the water depth of the features and their correspondence to past sea-levels (Miller et al., 2020).

Direct dating of such mounds is difficult. Their outer crust, which divers and ROVs can sample, may be entirely coated by encrusters that colonized after the formation of the core of the mounds. Meanwhile, drilling the biogenic mounds is technologically challenging and expensive, and destructive methods may not be suitable for such an environmentally sensitive environment. Furthermore, the features themselves might be, in part, the product of erosion, complicating dating even further. As such, all age estimations for these moundes are limited and at times speculative.

\subsection{Biogenic mounds in the Mediterranean Sea}




\section{Running Title}

Subdivision of modes of carbonate production (carbonate factories) shows the Mediterranean carbonate production to be unique because it is dominated by a light-governed C-type factory (Reijmer, 2021). Production is dominated by phototrophs that are not corals. This type of production is characterized by a small production centre. Where biogenic mounds have been reported in the Mediterranean Basin they tend to be significantly smaller than their Atlantic counterparts (Matos et al., 2017). Mediterranean biogenic mounds are typified by cold-water coral growth at their tops and/or flanks. Biogenic mounds have been reported in the Alboran Sea, Tyrrhenian Sea, the Ionian Sea and the Levantine Sea (Aloisi et al., 2000; Remia and Taviani, 2005; Taviani et al., 2005, 2013; Savini et al., 2009, 2014; Corbera et al., 2019). Most of these mounds occur at depths of $>200 \mathrm{~m}$. Increased exploration of the mesophotic domain has led to discovery of biogenic mounds in such depths as well, revealing a diverse range of bioconstructions (Ingrosso et al., 2018). Among the most representative habitats is the coralligenous, with a wide range of morphotypes (Ballesteros et al., 2006; Bracchi et al., 2017), which are generally not associated with mound-like features. Biogenic mounds $<100 \mathrm{~m}$ in diameter and located in mesophotic depths have only been described in a few locations in the Mediterranean Sea (Savini et al., 2014; Violante et al., 2020). Notably these studies do not report coralligenous or algal reefs components. The assemblage building the mounds vary depending on depth, temperature and tropic state. It may be dominated by bryozoans (James et al., 2004), cold water corals such as Lophelia pertusa and Madrepora oculate (Dorschel et al., 2007; Foubert et al., 2008), sponges (de S. Carvalho et al., 2016; Goren et al., 2021) or a combination of corals and coralline algae (Amado-Filho et al., 2016; Dumalagan et al., 2019). In some cases, based on geochemical and morphological evidence, it was possible to associate the origin of some of the deeper of these mounds to hydrocarbon seepage (Cangemi et al., 2010). However, the origin of the biogenic mounds is less clear in shallower waters where phototrophic calcifiers are present at the surface of the mound (Violante et al., 2020). 


\subsection{This study}

Here, we report on the extensive occurrence of biogenic mounds offshore the Maltese Islands (Sicily Channel). The objectives of our study are to quantify the geometry and distribution of these biogenic mounds and to characterize their environment. Based on this information, we discuss the possible origin of these features, as well as the risks they presently face.

\section{$2 \quad$ Regional setting}

The Maltese archipelago (Figure 1) is located in the central Mediterranean Sea, between Sicily and North Africa, in an elevated region called the Malta Plateau. The latter is a $150 \mathrm{~km}$ long and 120 $\mathrm{km}$ wide ridge located in the north-eastern part of the Pelagian Platform, which separates the eastern and western Mediterranean. The Maltese Islands comprise one of the few emergent areas of the Pelagian carbonate platform. Outcropping across the Maltese Islands are shallow $(<500 \mathrm{~m})$ water, Oligo-Miocene pre- to syn-rift sedimentary successions (Pedley et al., 1976). The entire sequence is disrupted by two normal fault systems (Illies, 1980; Gardiner et al., 1995). The first is a system of syn-depositional ENE-WSW trending faults, which were active intermittently between the Early Miocene and mid-Pliocene. The second system consists of NW-SE trending faults that were formed or re-activated in the late Pliocene to Quaternary. The seafloor around the archipelago, which is one of the least studied areas in European seas, is characterized by a smooth and gently sloping seabed, predominantly 100-150 m in depth, although it locally reaches depths of $400 \mathrm{~m}$. The seafloor is mostly covered by a thin layer of sand to silt sized biogenic sediments with local baffling by seagrass or red algae (Micallef et al., 2013). Seepage of methane and carbon dioxide has been documented across the Malta Plateau, also in proximity of the Maltese Islands (Cangemi et al., 2010; Micallef et al., 2011, 2019). Buried bodies of freshened groundwater have been reported offshore eastern Malta; the source of this groundwater is likely topographically-driven meteoric recharge during sea-level lowstands (Haroon et al., 2021). The water column is stratified in the boreal summer and remixes in the boreal winter (Drago et al., 2003). Winter temperature in the upper $200 \mathrm{~m}$ is around $15^{\circ} \mathrm{C}$ while the upper $100 \mathrm{~m}$ can warm to $\sim 25^{\circ} \mathrm{C}$ in summer. The warmer water comes from the south-east and is driven by anticyclonic flow forced by northwestern cool water flowing into the eastern Mediterranean. 


\section{Running Title}

\section{$3 \quad$ Materials and methods}

The study area is located offshore of the south-eastern coast of Malta (Figure 1). It comprises 250 $\mathrm{km}^{2}$ of seafloor ranging between 0 and $140 \mathrm{~m}$ in depth, with a substrate of maerl, gravel, sand and bedrock outcrops. The key morphological features in the study area are seven fault-related escarpments.

Two types of seafloor data were collected from the study area between 2006 and 2021:

\subsection{Multibeam echosounder data}

The multibeam echosounder data available for this study were acquired during four different oceanographic expeditions: (i) MALTA2021 cruise conducted on board the Goldfinder in 2021 using a Norbit iWBMS system operating at a frequency of $400 \mathrm{kHz}$. (ii) SO277 cruise on board the R/V Sonne in 2020 using a Kongsberg EM 710 system. (iii) Gas pipeline reconnaissance survey carried out by Melita Transgas Ltd in 2018, using a R2Sonic 2024 system. (iv) HMS Roebuck cruise in 2006 using a Kongsberg EM-1002 system.

Post-processing of the multibeam bathymetry data from these surveys, which included correction for heading, depth, pitch, heave and roll, was conducted using Qimera. Tide and sound velocity profile corrections were applied and the sounding data cleaned to remove erroneous soundings. Bathymetric data were gridded to 1-2 m digital elevation models (DEM). Backscatter data were processed using Fledermaus FMGT at 0.2-1 m.

Mapping of mounds in the study area was carried out using the BGS Seabed Mapping Toolbox developed in 2017 by the British Geological Survey (Gafeira et al., 2018). This toolbox contains four main tools: Feature Delineation Tool, BPI-based Delineation Tool, Feature Short Description Tool, and Feature Full Description Tool. We decided to use the Feature Delineation Tool to delineate confined positive features directly from the bathymetric data. To run the tool, five values - Cutoff Vertical Relief, Minimum Vertical Relief, Minimum Width, Minimum Width/Length Ratio and Buffer Distance - had to be defined. The Cutoff Vertical Relief defines the contour line that will be used to delineate the features; the values set for the Minimum Vertical Relief, Minimum Width and Minimum Size Ratio define the thresholds above which features are going to be mapped. Finally, the Buffer Distance compensates for the fact that the delineation process is based on the features' internal contour line, which corresponds to the Cutoff Vertical Relief threshold. For this study we used a Cutoff Vertical Relief of $0.2 \mathrm{~m}$, a Minimum Width of $10 \mathrm{~m}$, a Minimum Width/Length Ratio of 0.2, and a Buffer Distance of 5m; these values have been kept fixed for each mapping operation. The Minimum Vertical Relief was the only parameter that was varied. We tried 
different values $-10 \mathrm{~m}, 15 \mathrm{~m}, 20 \mathrm{~m}$, and $30 \mathrm{~m}$ - in order to detect morphologies having different extents. The output of this tool was a shapefile of polygons that delineated the mapped features, and a text file reporting the information about the script, input data and parameters used. The extracted polygons were visually compared with the available bathymetry and backscatter data to eliminate features resulting from acquisition artefacts.

\subsection{Imagery and samples}

ROV surveys were carried out in 2014 and 2021. The 2014 survey was carried out on the R/V Hercules using a Seaeye Panther Plus equipped with a Kongsberg High-Definition color camera. The 2021 survey was carried out on the Delfino and utilised a Shandong Future Robot Co. VVLV400-4T Underwater Inspection ROV with a Digital HD color 2 megapixel camera. During these surveys, spot dives were carried out at $60 \mathrm{~m}$ deep mounds located east of Delimara. Technical dives were carried out in the summer of 2021, during which photographs and samples were collected from mounds at 90-100 m depths. These samples included hand samples of the exposed rock and adjacent sediment in random locations that were easily accessible for the divers. Hand samples were washed with fresh water and air dried before being described. One large rock sample was cut and polished. Sediment samples were visually described. 


\section{Running Title}

\section{Results}

\subsection{Multibeam echosounder data}
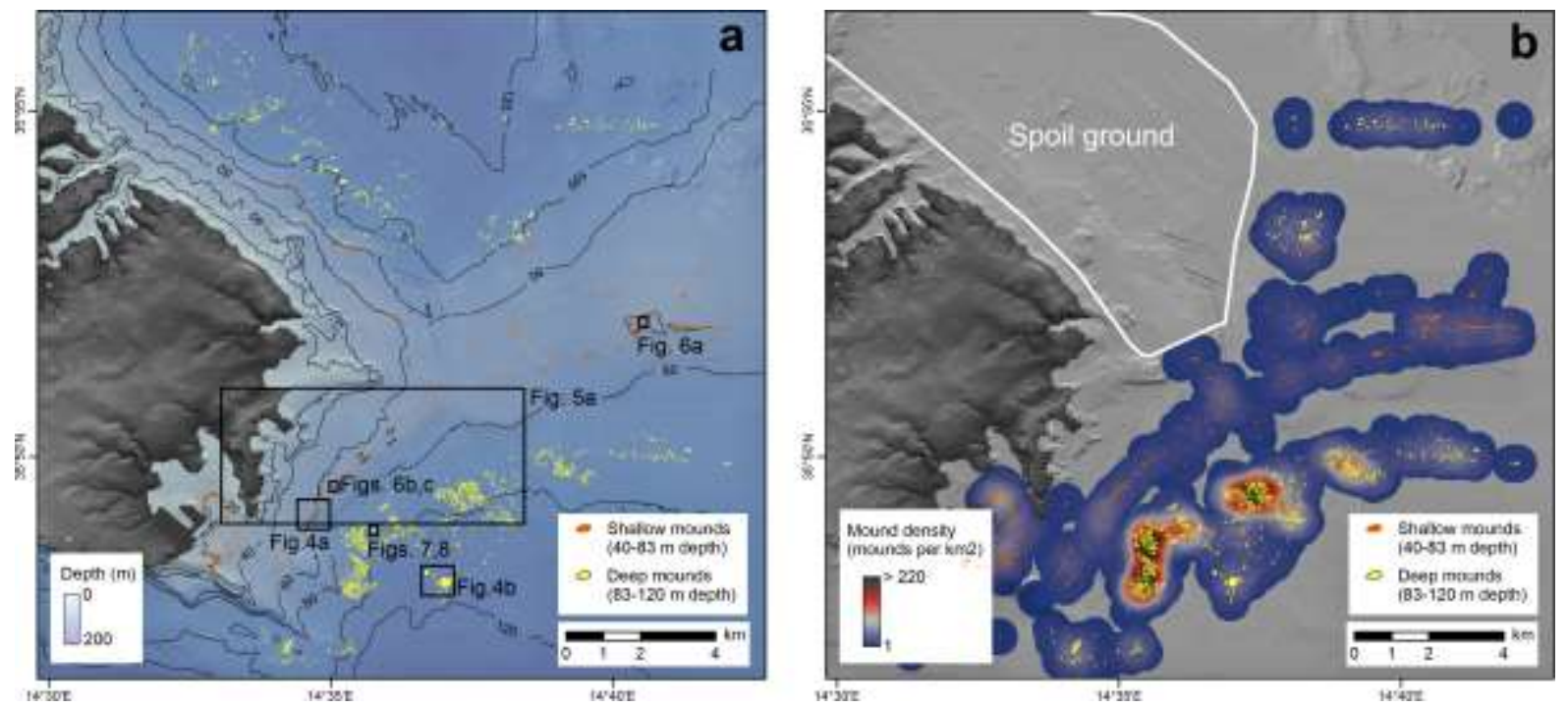

Figure 2: a. Output of automated mapping showing the locations of the mounds; $b$. Density map with $1000 \mathrm{~m}$ search radius highlighting areas of high mound density and locations of spoil grounds.

\subsection{Mounds}

Automated mapping has identified 2332 mounds across the surveyed area (Figure 2). An area near port of Valletta is known spoil grounds and excluded from our analysis, leaving 1770 mounds. These features, identified as mounded bioconstructions by subsequent dives (see section 4.4), range in area from a few $\mathrm{m}^{2}$ to $>10,000 \mathrm{~m}^{2}$ (Figure 3a). Mounds have a mean area of $\sim 600 \mathrm{~m}^{2}$ and a mean diameter of $\sim 20 \mathrm{~m}$. Most mounds inhabit swaths of 500 to $1000 \mathrm{~m}$ of relatively flat seafloor and are found between 60 to $120 \mathrm{mbpsl}$ (meters below present sea level). Spatially, the mounds can be grouped into two main clusters based on depth (Figure 3b), from 40 to 83 mbpsl (Figure 4a) and from 83 to 120 mbpsl (Figure 4b). Spatially, the mounds are clumped together, often aligning along isobaths (Figure 2). There is no clear relation between the mound size and water depth, and all clusters exhibit similar size distributions. The mean distance between mounds is $61 \mathrm{~m}$ for the entire population. Densities in between 60 and $70 \mathrm{mbpsl}$, as well as 90 to $100 \mathrm{mbpsl}$, are greater, with a mean distance between mounds of $47 \mathrm{~m}$. In some places, mounds are aligned and exhibit some linearity or conformity to an isobaths (Figure 2). Notably, at around $80 \mathrm{mbps}$ the mounds are located on or near escarpments. Due to their clustering and the adjacency of some mounds and structures to such escarpments, elevation extraction was not very reliable. If we limit our analyses to mounds not forming part of clusters and removed from such structures, estimated elevations are 1-5 $\mathrm{m}$ above the local topography. On multibeam backscatter data (Figure 5) the mounds are characterized by high acoustic reflectivity, with the surrounding seafloor having intermediate 
acoustic reflectivity. The seafloor away from the mounds is characterized by low acoustic reflectivity.
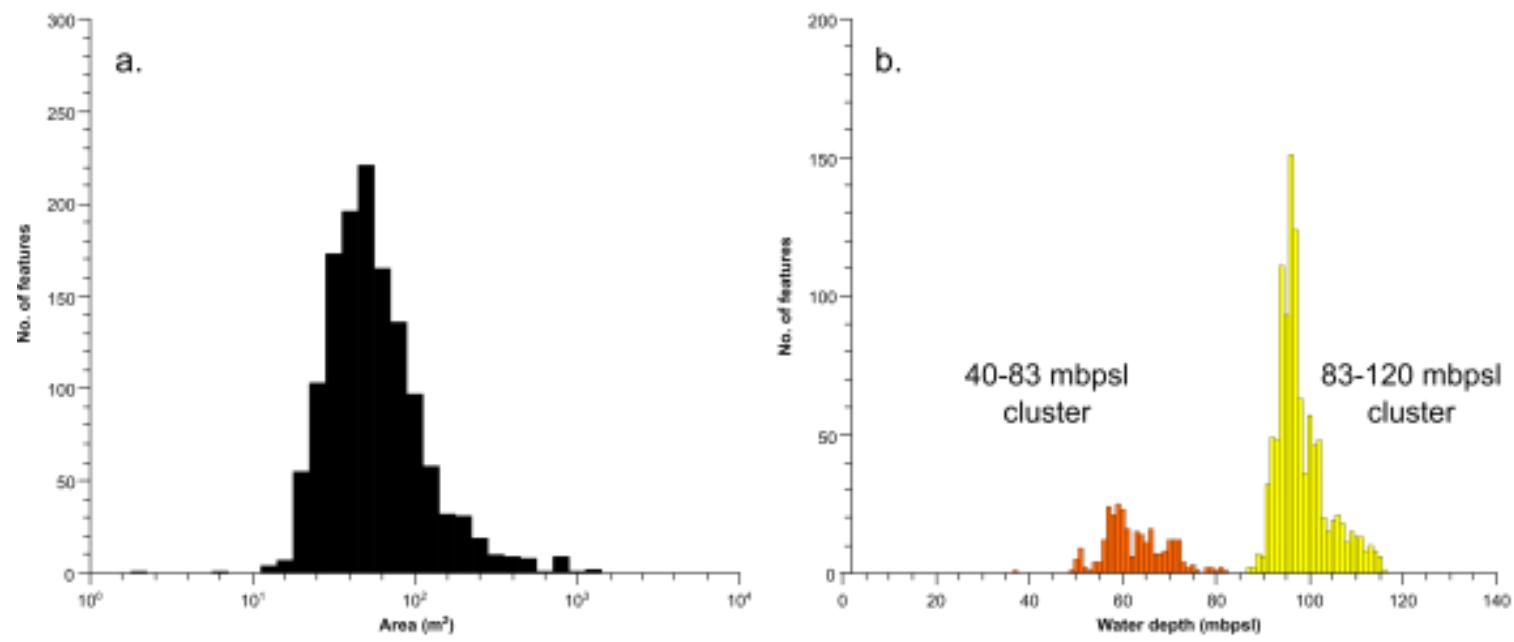

Figure 3: Histograms of a. area, b. water depth of the base of the mounds.
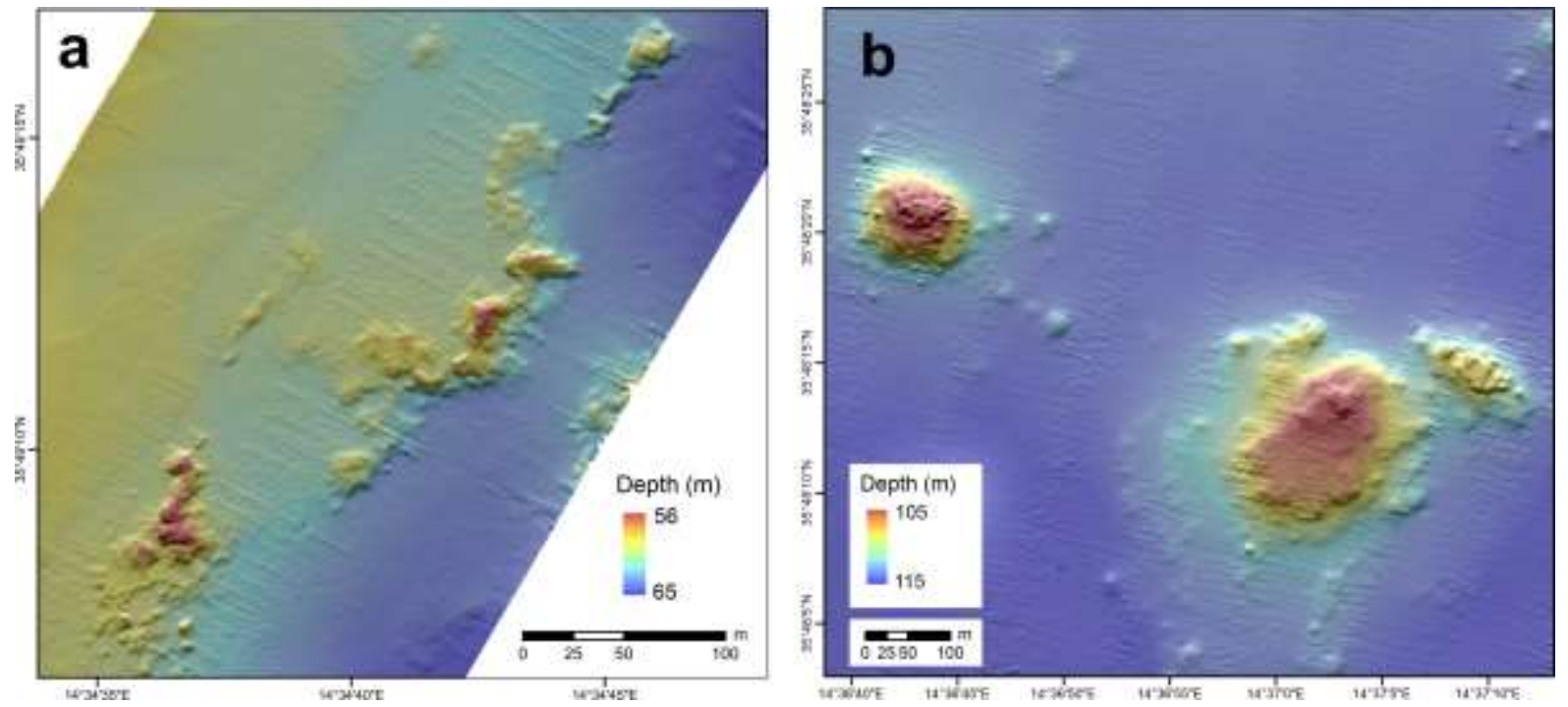

Figure 4: Bathymetric maps of the mounds. a. case example for mounds in the 40 to $83 \mathrm{mbspl}$ clusters and b. case example for mounds in the 83 to $120 \mathrm{mbspl}$ cluster.

\subsection{Trawl marks}

The multibeam bathymetry and backscatter data reveal the presence of trawl marks across the entire study area (Figure 5a). Some trawl marks are also visible in the multibeam bathymetry data as narrow furrows that can be up to $20 \mathrm{~cm}$ deep (Figure 5b). In the backscatter imagery, trawl marks are displayed as narrow ( $4 \mathrm{~m}$ wide) areas of higher backscatter values compared to the surrounding seafloor (Figure 5c). Trawl marks range from about $20 \mathrm{~m}$ to over $4.5 \mathrm{~km}$ in length, having both 


\section{Running Title}

straight and curved forms. They generally appear as individual features, although parallel marks are also visible with a mean distance of $60-70 \mathrm{~m}$. In some trawl marks, positive relief $(\sim 5 \mathrm{~cm}$ high $)$ can be identified along both sides of the furrow, indicating pushed up sediments.
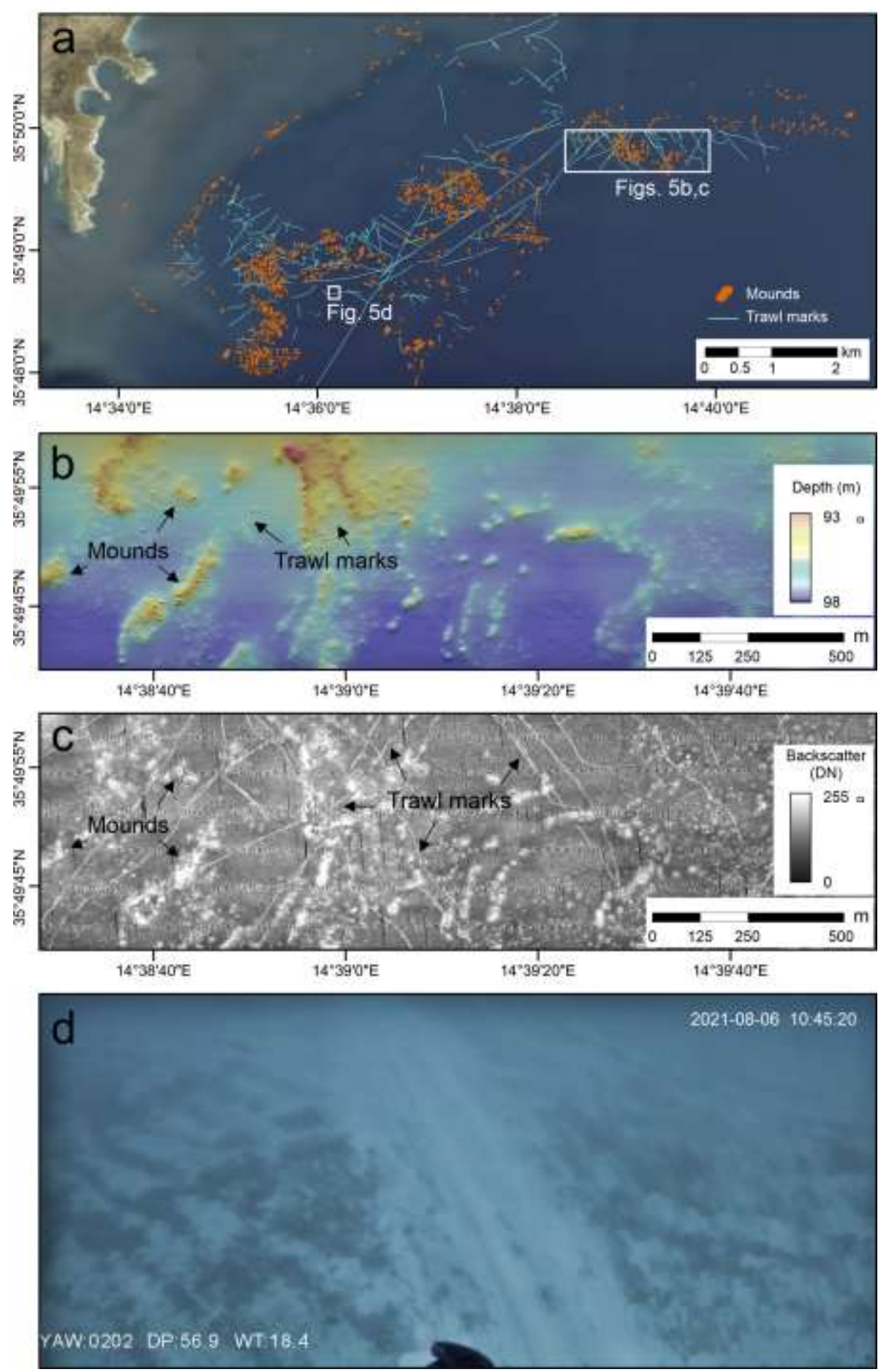

Figure 5: Evidence of trawlmarks in the study area. A. Map showing trawl marks occurrence in the study area. b. Shaded-relief colour multibeam bathymetry and c. Backscatter imagery of an area of mounds highly impacted by trawling; d. ROV image of a trawl mark probably caused by a trawl door.

\subsection{Imagery and samples}


In all locations surveyed with ROV, the mounds were found to be rock outcrops that are usually composed of an agglomeration of rocks spread across a small area. (Figures 6a, b \& 7a). A fair number of the rocks are taller than they are wide. In most cases, they do not appear to be detached boulders but extend into the subsurface. The rocks are for the most part rounded, although locally jagged and with sharp edges, notably around $60 \mathrm{mbpsl}$. The surface of the rocks forming the mounds is irregular with some crevasses and an overall rugose texture where the rock surface is exposed.

Sediment adjacent to the mounds at around $60 \mathrm{mbpsl}$ (Figure 6c) is arranged in small ripples with a dark crest. Trawl marks are present and visible within a short distance of the mounds visited during the dives (Figure 5a, d). Mounds found around a depth of $60 \mathrm{~m}$ appear in two forms: in the north of the study area, they are extensively covered by soft body fouling, including short seagrass as well as possible hydrozoans and macroalgae, although no clear calcifiers are present (Figure 6a). In the south of the study area, the mounds are barren with some sediment coating (Figure 6b).

Sediment adjacent to mounds at around $90 \mathrm{mbspl}$ also exhibit some ripples, but these do not exhibit any consistent character. The seafloor, however, does exhibit significantly more bioturbation activity (Figure 6b). The sediment around the mounds shows variability in grain size over short distances. On some sides of the mound, the sediment consists of fine to medium sand in size (Wentworth scale), whereas on other sides the sediment ranges from fine to very coarse sand in size. The coarser grains have poor roundness and sphericity and are composed of fragments of branching bryozoans, shell fragments and other unidentified bioclasts. Based on the sediment samples and optical imagery, the higher acoustic reflectivity in the backscatter data (Figure 5c) appears to be associated with coarse-grained material whereas the lower reflectivity is finer-grained sediment. 


\section{Running Title}
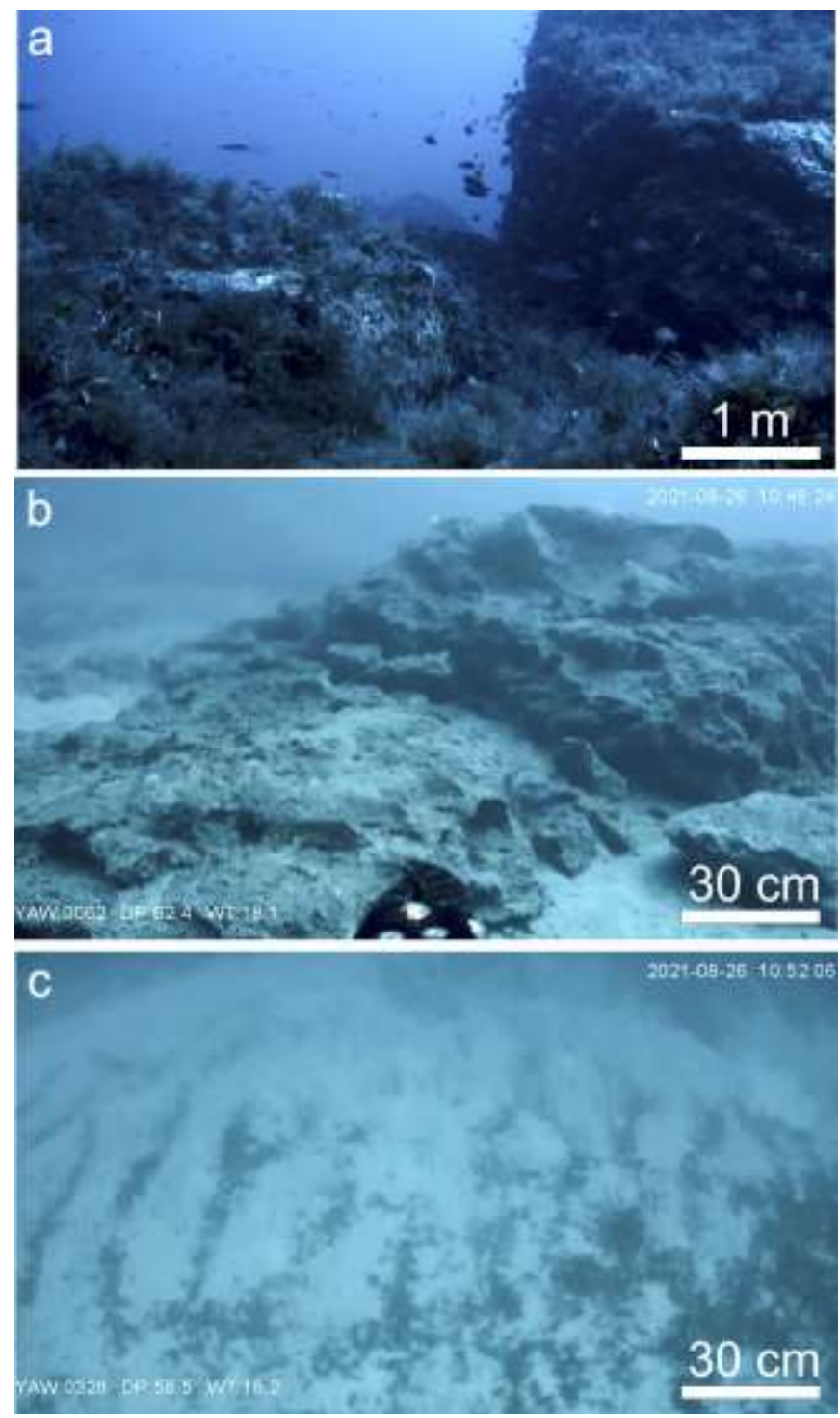

Figure 6: Imagery of mounds from the $60 \mathrm{~m}$ cluster. a. rock outcrops in mounds from the $60 \mathrm{~m}$ clusters in the northern part of the study area; b. rock outcrops in mounds from the $60 \mathrm{~m}$ clusters in the southern part of the study area. c. sediment ripples adjacent to a mound in the $60 \mathrm{~m}$ cluster from the southern part of the study area.

The crust of the mounds was sampled from a mound at $~ 90 \mathrm{mbpsl}$. The crust is calcareous (Figure 8a) and composed of interlocking meshes of different encrusting organisms, including coralline algae (Figure 8b), serpulids, bryozoans and foraminifera. These appear to trap fine micritic material and exhibit areas with iron oxides (Figure 8c). The serpulids are varied in form and appear to include worms as well as possible vermetid gastropods and encrusting foraminifera (Figure 8d). The outer coating of the crust is covered by encrusters such as vermiforms, crustose coralline algae and small attached bivalves. The mounds found between 90 and 100 mbpsl exhibit different levels of fouling (Figure 7c-f). The mounds' surfaces show multiple reddish patches (Figure 7c), which appear to be crustose coralline algae and possibly encrusting foraminifera. Additionally, the surface is covered by different types of vermiforms (serpulids). Cold water corals (Anthipatarians and gorgonians), echinoderms, sea urchins, sea snails and sponges are attached to the surface (Figure $7 \mathrm{c}-\mathrm{f})$. Some spots of barren rocks and with a thin sediment coating are also present. In some locations, there is a notch at the base of the mounds (Figure 7f), but it is not clear if it is erosive or 
the product of differential growth of mounds crust. Multiple fish and fish types were observed in the vicinity of the mounds at all depths.

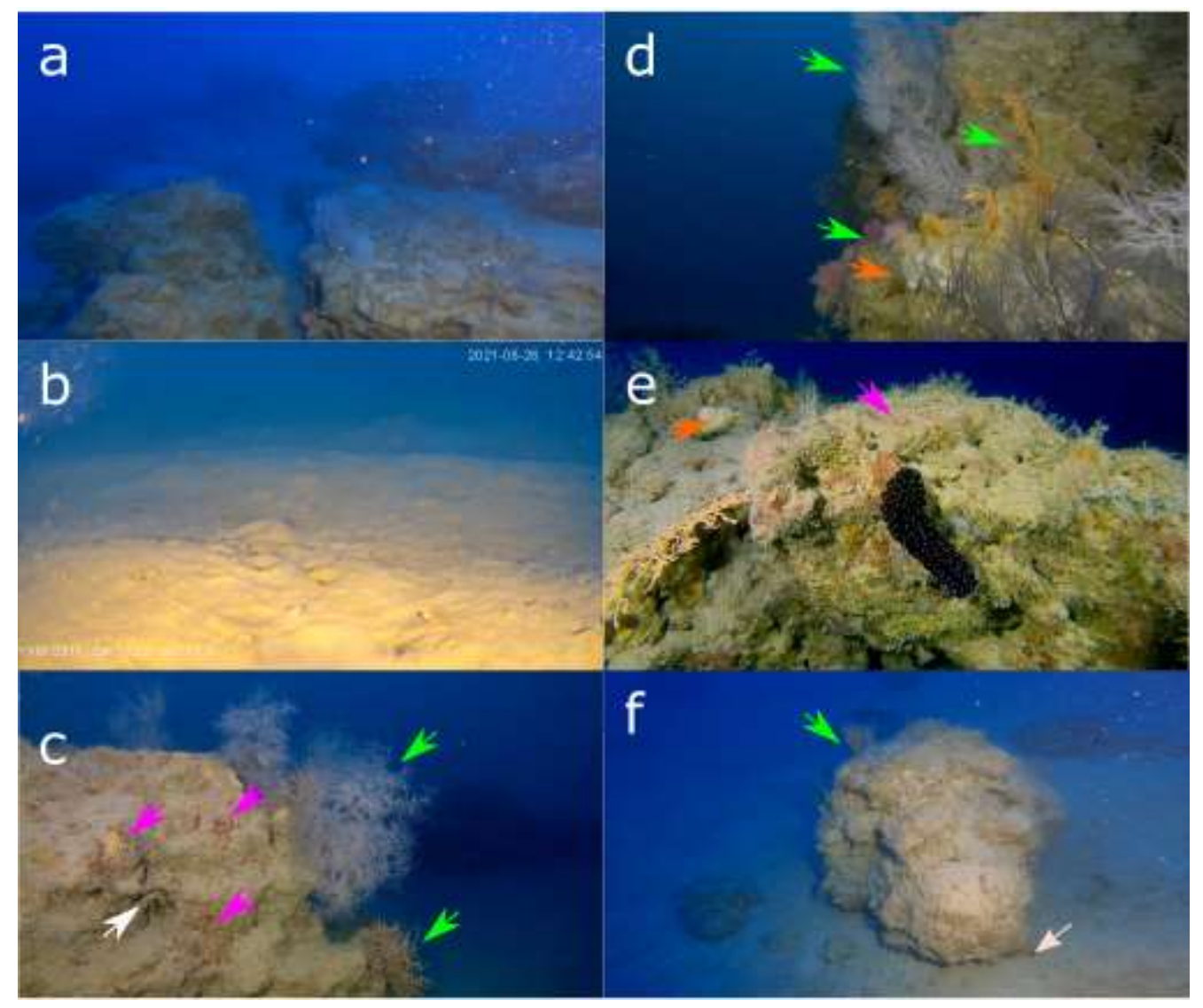

Figure 7: Imagery from mounds at $90 \mathrm{mbpsl}$. a. rock outcrops in mounds from in the southern part of the study area; b. sediments adjacent to a mound in the southern part of the study area; c. rock outcrop from a mound in the southern part of the study area with red alga (magenta arrows), Anthipatarians (green arrows) and sea urchin (white arrow); d. rock outcrop from a mound in the southern part of the study area with Anthipatarians and gorgonian (green arrows, white and orange specimens, respectively) and sponges (orange arrow); e. rock outcrop from a mound in the southern part of the study area with a sea slug note also sponges (orange arrow) and red alga (magenta arrows). f. rock outcrop from a mound in the southern part of the study area with a notch at the base (pinkish-white arrow). 


\section{Running Title}

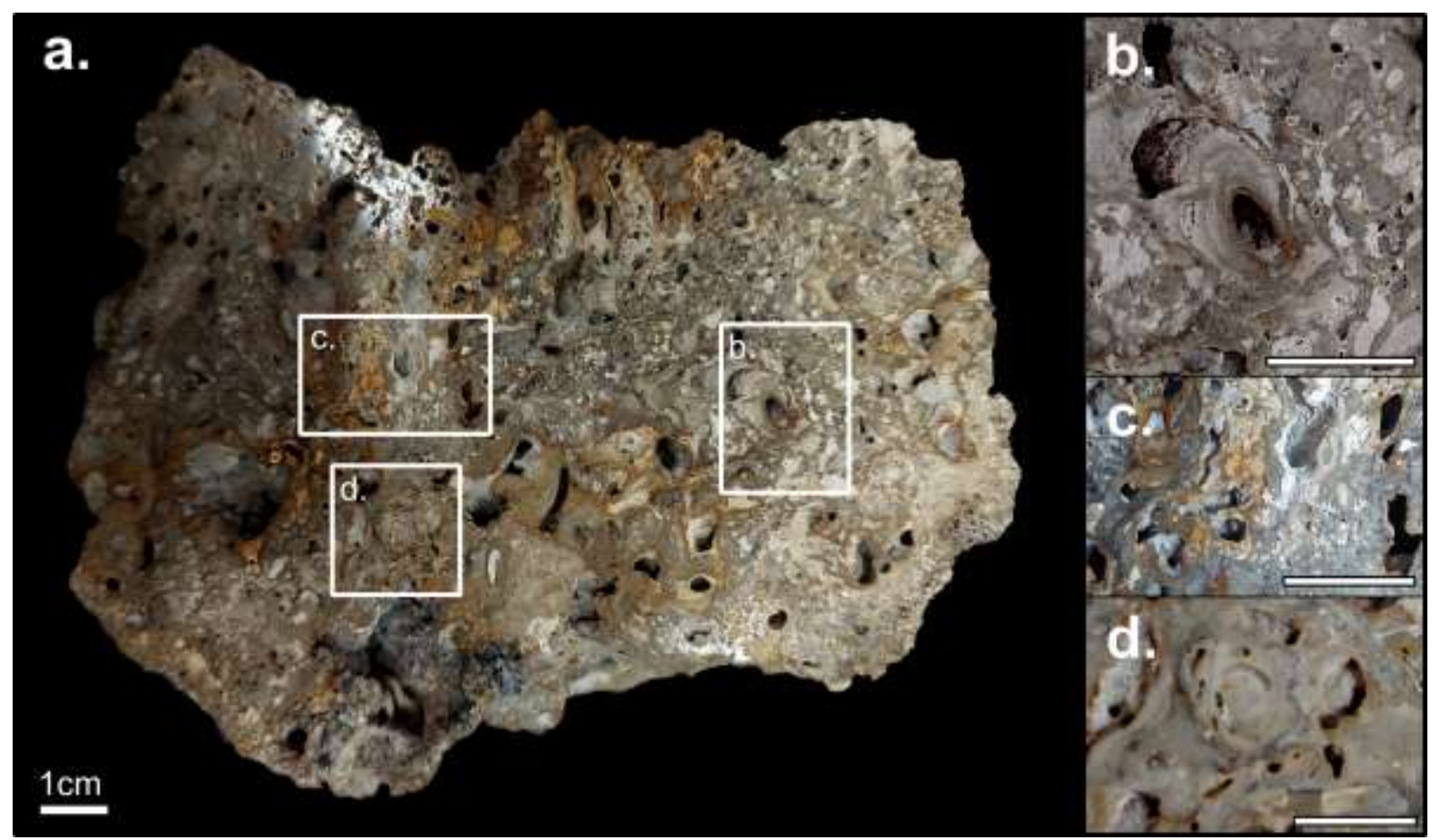

Figure 8: a. Polished slab of surface crust samples of a mound from the at $90 \mathrm{mbpsl}$ (Figure 4). b. coralline algae rounded encrustation. c. iron oxide staining. d. serpulid. All scale bars are $1 \mathrm{~cm}$.

\section{Discussion}

\subsection{Origin of mounds}

Presently $>1700$ features can be found in water depths of 40 to 120 mbpsl offshore SE Malta. These are mounded bodies composed of bioconstruction, which we identify as biogenic mounds. When inspected these mounds were found to be elevated carbonate edifices with minor biogenic coating. These structures, only several meters in height, are much smaller and denser than cold water coral mounds described in greater depths in the Mediterranean (Remia and Taviani, 2005; Savini et al., 2014; Corbera et al., 2019). As such, their genesis is probably somewhat different. The carbonate is a collection of encrusting organisms that have accumulated over time and make the outer shell of the mound. However, the inner structure is unknown. We consider three potential origins for the underlying core of the mounds:

(i) geological boulders: The mounds are comparable in shape to boulders found along the present Maltese shoreline, which have been attributed to extreme storm events or tsunamis (Biolchi et al., 2016). However, our mounds are larger, more numerous, and not clustered near any steep topography (onshore and offshore) but rather far from them or even above. As such, the mounds are probably not boulder accumulations with subsequent encrusting. 
(ii) ancient shallow water biogenic reefs: In high latitudes and deep waters, the growth of mounds is limited to interglacial periods as glacier growth limits their development during glacial periods (Rüggeberg et al., 2007). However, in lower latitudes and shallower depths, such as our study area, the opposite may occur. Mounds may develop in what are now mesophotic depths as euphotic reefs during glacial times and then drown during interglacial periods (Webster et al., 2004; Beaman et al., 2008). These drowned reefs often form or reside atop terraces formed during prolonged periods of relatively stable sea-level over the last glacial cycle (Carter et al., 1986; Grigg et al., 2002). Mounds found between 40 and 83 mbpsl inhabit surfaces formed during MIS5 and MIS3-4 lowstands (Figure 9). As the substrate of the mounds, under a thin sediment coating, is probably geological rock, extensive truncation is needed to clear such a surface. Coastal retreat of rocky shores in the North Atlantic (where tides and weather are more abrasive than the central Mediterranean) has been estimated at $\sim 7 \mathrm{~cm} / \mathrm{yr}$ (Lim et al., 2010). As such abrasion of the terraces the mounds inhabit in the 40 to 83 mbpsl cluster will be in the order of thousands of years, much longer than the short standstills of the post-glacial transgression, and more likely related to earlier stages such as MIS 5 to 3. Colonization likely occurred both during that time and during the postglacial transgression.

(iii) authigenic carbonate edifices related to seepage: The above explanation (ii) does not apply well to the more numerous features between 83 and $120 \mathrm{mbpsl}$. This is because they reside in depths that do not correspond to any distinct standstill in the last glacial cycle or the preceding one (Figure 5). These could, instead, be the product of seepage of two types of fluids: meteoric groundwater or hydrocarbons (notably methane). The scenario for the former would entail meteoric groundwater discharging at the coast or shallow seafloor (submarine groundwater discharge). Such discharge would have been enhanced during glacial drawdowns due to the development of higher hydraulic (Faure et al., 2002). The seeps would lead to the accumulation of authigenic carbonates or alternatively provide a local nutrient spike (Knee et al., 2016; Gierlowski-Kordesch et al., 2021) that could promote colonization. These initial edifices could be colonized at later times and continue to accumulate in the available hard substrate (Hovland and Risk, 2003). Such a scenario is feasible in view of the occurrence of coastal discharge at present (Sustainable Energy and Water Conservation Unit, 2015) and the occurrence of freshened groundwater offshore the coast of SE Malta, which is thought to have been emplaced during sea-level lowstands (Haroon et al., 2021). Extension of the groundwater body underneath the Malta Plateau across the entire depth range of the mounds during glacial periods is likely. A second scenario entails the escape of methane at the seafloor. Micallef et al. (2019) documented an active fluid system responsible for degassing of methane onshore and offshore the Maltese islands, with the fluid flowing preferentially along faults 


\section{Running Title}

and, occasionally, pipe structures. The localization of these seeps on preexisting flow paths such as faults (including blind faults) could explain some of the linearity observed in some of the clusters.
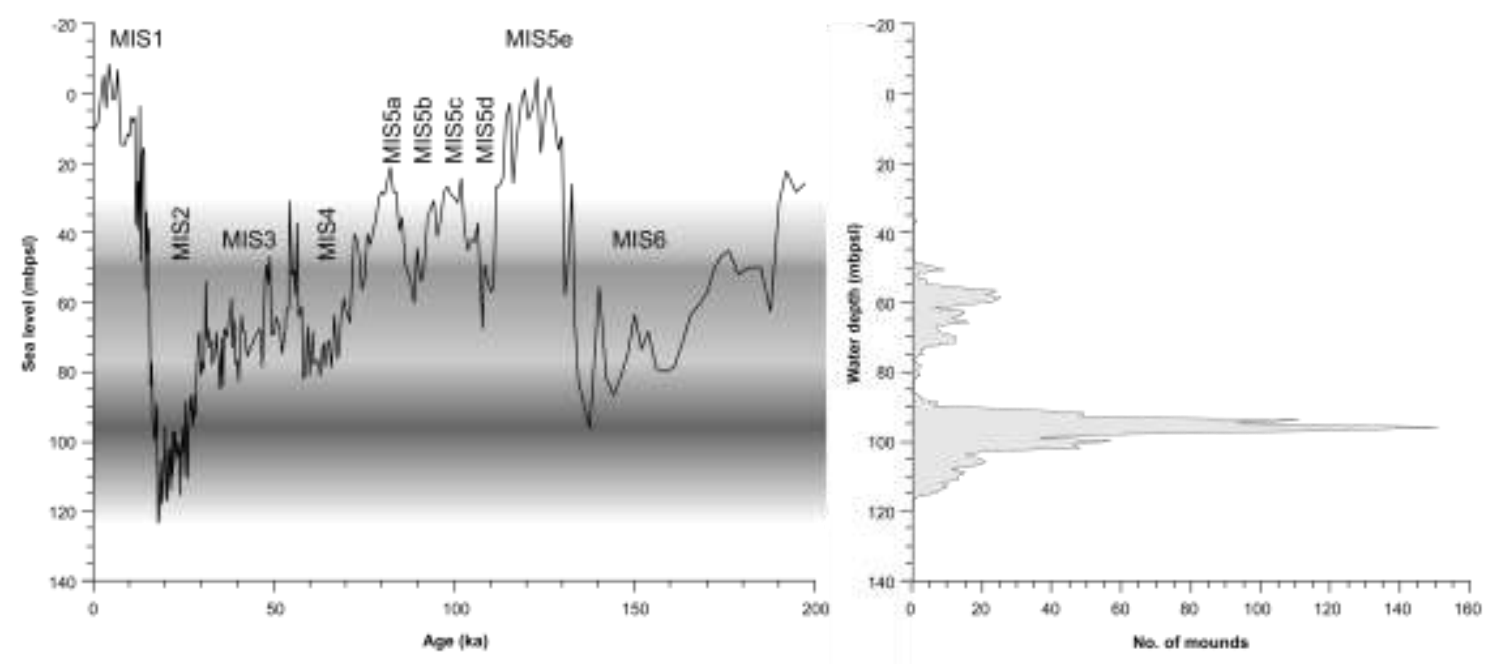

Figure 9: Water depth ranges of the mounds (right) relative to sea-level curve of the last glacial cycle (left, Miller et al., 2020). Note that most of the mounds relate to water depths associated with low stands. Grey gradient illustrates relative density of mounds in a given depth.

At present, the mounds appear to be living mesophotic reefs, offering refuge and feeding grounds for planktonic and benthic organisms as well as a hard substrate for recruitment (Figure 6). Assuming a conservative $1 \mathrm{~mm} /$ year growth rate based on the coralline algae for their accretion (Caragnano et al., 2016), had their current phase of accretion begun in the post last glacial maximum transgression, that would allow for $\sim 1.5 \mathrm{~m}$ of buildup in the for the sub 83 to $120 \mathrm{mbpsl}$ cluster. Given the strong vertical component of some of the observed elements (e.g. Figure 6i), it is likely much of this growth was vertical. However, this vertical growth could not keep up with the rapid rate of sea-level rise during the last glacial cycle (Lambeck et al., 2011). If the sedimentation rate on the Malta Plateau were higher than the growth rate, it is likely many of these mounds would have been buried and not exposed at the surface. The mounds appear to be local sources of sediment, as evident by the larger grains size of the sediment near the mounds. As such, it is likely that the low sedimentation rate in the area was key to the extensive occurrence and preservation of the mounds.

\subsection{Risks to biogenic mounds}

The mounds offshore SE Malta and the species they host (notably black corals) deserve protection. Unfortunately, the mounds are exposed to intensive anthropogenic stress. The trawl marks that crisscross across the study area, which we predominantly associate to fishing and anchoring activities (Figure 6), have damaged the mounds directly and negatively affected the filter-feeding 
organisms that build them via sediment resuspension. Urgent legislative action is therefore required to declare the seafloor offshore SE Malta as a Marine Special Area of Conservation.

\section{Conclusions}

We have identified hundreds of small elevated features offshore eastern Malta which we identified as biogenic mounds. These mounds are clustered in two main groups, between 40 to 83 and 83 to 120 mbpsl. The mounds are rocky, composed of interlocking biogenic encrustation by calcifiers. They are a few meters in height and up to a few tens of meters in diameter, occurring mostly as relatively tight clusters. Their origin is unclear; given their composition, these structures likely took several thousands of years to reach their current size, or possibly longer. It is not unlikely that they two clusters formed by different mechanisms. The 40 to 83 mbpsl cluster being dominantly drowned reefs formed upon terraces excavated in the last glacial cycle. Meanwhile the 83 to 120 mbpsl likely had a more complicated formation mechanism, possibly also involving fluid seepage. Presently, their surface is covered by a mesophotic hard bottom community including black corals, sponges and other encrusters. These structures are special and a unique ecotope currently that would have required prolonged stable conditions to grow, but is currently under risk from anthropogenic activity. Mostly directly, trawling activity is extensive around these features and may lead to their imminent destruction.

\section{Acknowledgements}

This research was supported by the Marie Sklodowska-Curie grant agreements no. 101003394 (RhodoMalta) and 867471 (TrawledSeas), and the European Research Council (ERC) (grant agreement no. 677898; MARCAN), under the European Union's Horizon 2020 Research and Innovation Programme, the University of Malta and the SMART Project through the Helmholtz European Partnering Initiative (Project ID Number PIE-0004). We kindly acknowledge the captain, crew and scientists on the R/V Sonne expedition SO277 for their assistance with data collection, and Kevin Sciberras for organising the dive surveys onboard the Delfino. We are grateful to the UK Hydrographic Office and Melita Trangas Co. Ltd for providing access to their data. The surveys were possible following permits issued by the Department of Continental Shelf, the Environment and Resources Authority, the Superintendence of Cultural Heritage and the Ports and Yachting Directorate. 


\section{Running Title}

\section{References}

Abbey, E., Webster, J. M., Braga, J. C., Jacobsen, G. E., Thorogood, G., Thomas, A. L., et al. (2013). Deglacial mesophotic reef demise on the Great Barrier Reef. Palaeogeogr. Palaeoclimatol. Palaeoecol. 392, 473-494. doi:10.1016/j.palaeo.2013.09.032.

Aloisi, G., Pierre, C., Rouchy, J. M., Foucher, J. P., and Woodside, J. (2000). Methane-related authigenic carbonates of Eastern Mediterranean Sea mud volcanoes and their possible relation to gas hydrate destabilisation. Earth Planet. Sci. Lett. 184, 321-338. doi:10.1016/S0012$821 \mathrm{X}(00) 00322-8$.

Amado-Filho, G. M., Moura, R. L., Bastos, A. C., Francini-Filho, R. B., Pereira-Filho, G. H., Bahia, R. G., et al. (2016). Mesophotic ecosystems of the unique South Atlantic atoll are composed by rhodolith beds and scattered consolidated reefs. Mar. Biodivers. 46, 933-936. doi:10.1007/s 12526-015-0441-6.

Ballesteros, E., Avançats, E., and Csic, D. B. (2006). Mediterranean Coralligenous Assemblages : a Synthesis of Present Knowledge. Communities 44, 123-195. doi:10.1016/j.jenvman.2012.07.024.

Bare, A. Y., Grimshaw, K. L., Rooney, J. J., Sabater, M. G., Fenner, D., and Carroll, B. (2010). Mesophotic communities of the insular shelf at Tutuila, American Samoa. Coral Reefs 29, 369-377. doi:10.1007/s00338-010-0600-y.

Beaman, R. J., Webster, J. M., and Wust, R. A. J. (2008). New evidence for drowned shelf edge reefs in the Great Barrier Reef, Australia. Mar. Geol. 247, 17-34. doi:10.1016/j.margeo.2007.08.001.

Biolchi, S., Furlani, S., Antonioli, F., Baldassini, N., Causon Deguara, J., Devoto, S., et al. (2016). Boulder accumulations related to extreme wave events on the eastern coast of Malta. Nat. Hazards Earth Syst. Sci. 16, 737-756. doi:10.5194/nhess-16-737-2016.

Bracchi, V. A., Basso, D., Marchese, F., Corselli, C., and Savini, A. (2017). Coralligenous morphotypes on subhorizontal substrate: A new categorization. Cont. Shelf Res. 144, 10-20. doi:10.1016/j.csr.2017.06.005.

Cangemi, M., Di Leonardo, R., Bellanca, A., Cundy, A., Neri, R., and Angelone, M. (2010). Geochemistry and mineralogy of sediments and authigenic carbonates from the Malta Plateau, Strait of Sicily (Central Mediterranean): Relationships with mud/fluid release from a mud volcano system. Chem. Geol. 276, 294-308. doi:10.1016/j.chemgeo.2010.06.014.

Caragnano, A., Basso, D., and Rodondi, G. (2016). Growth rates and ecology of coralline rhodoliths from the Ras Ghamila back reef lagoon, Red Sea. Mar. Ecol. 37, 713-726. doi:10.1111/maec.12371.

Carter, R. M., Carter, L., and Johnson, D. P. (1986). Submergent shorelines in the SW Pacific: evidence for an episodic post-glacial transgression. Sedimentology 33, 629-649. doi:10.1111/j.1365-3091.1986.tb01967.x.

Corbera, G., Lo Iacono, C., Gràcia, E., Grinyó, J., Pierdomenico, M., Huvenne, V. A. I., et al. (2019). Ecological characterisation of a Mediterranean cold-water coral reef: Cabliers Coral Mound Province (Alboran Sea, western Mediterranean). Prog. Oceanogr. 175, 245-262. doi:10.1016/j.pocean.2019.04.010. 
de S. Carvalho, M., Lopes, D. A., Cosme, B., and Hajdu, E. (2016). Seven new species of sponges (Porifera) from deep-sea coral mounds at Campos Basin (SW Atlantic). Helgol. Mar. Res. 70, 10. doi:10.1186/s10152-016-0461-z.

Dorschel, B., Hebbeln, D., Foubert, A., White, M., and Wheeler, A. J. (2007). Hydrodynamics and cold-water coral facies distribution related to recent sedimentary processes at Galway Mound west of Ireland. Mar. Geol. 244, 184-195. doi:10.1016/j.margeo.2007.06.010.

Drago, A. F., Sorgente, R., and Ribotti, A. (2003). A high resolution hydrodynamic 3-D model simulation of the malta shelf area. Ann. Geophys. 21, 323-344. doi:10.5194/angeo-21-3232003.

Dumalagan, E. E., Cabaitan, P. C., Bridge, T. C. L., Go, K. T., Quimpo, T. J. R., Olavides, R. D. D., et al. (2019). Spatial variability in benthic assemblage composition in shallow and upper mesophotic coral ecosystems in the Philippines. Mar. Environ. Res. 150, 104772. doi:10.1016/j.marenvres.2019.104772.

Faure, H., Walter, R. C., and Grant, D. R. (2002). The coastal oasis: ice age springs on emerged continental shelves. Glob. Planet. Change 33, 47-56. doi:10.1016/S0921-8181(02)00060-7.

Foubert, A., Depreiter, D., Beck, T., Maignien, L., Pannemans, B., Frank, N., et al. (2008). Carbonate mounds in a mud volcano province off north-west Morocco: Key to processes and controls. Mar. Geol. 248, 74-96. doi:10.1016/j.margeo.2007.10.012.

Foubert, A., and Henriet, J.-P. (2009). Nature and Significance of the Recent Carbonate Mound Record. The Mound Challenger Code. Lect. Notes Earth Sci. 126, 298. doi:10.1007/978-3642-00290-8.

Gafeira, J., Dolan, M., and Monteys, X. (2018). Geomorphometric Characterization of Pockmarks by Using a GIS-Based Semi-Automated Toolbox. Geosciences 8, 154. doi:10.3390/geosciences8050154.

Gardiner, W., Grasso, M., and Sedgeley, D. (1995). Plio-pleistocene fault movement as evidence for mega-block kinematics within the Hyblean-Malta Plateau, Central Mediterranean. $J$. Geodyn. 19, 35-51. doi:10.1016/0264-3707(94)00006-9.

Gierlowski-Kordesch, E. H., Rothwell, G. W., Stockey, R. A., and Finkelstein, D. B. (2021). "Submarine Groundwater Discharge as a Catalyst for Eodiagenetic Carbonate Cements Within Marine Sedimentary Basins," in Limnogeology: Progress, Challenges and Opportunities: A Tribute to Elizabeth Gierlowski-Kordesch, eds. M. R. Rosen, D. Finkelstein, L. Park Boush, and S. Pla-Pueyo (Springer Nature), 445-468.

Glogowski, S., Dullo, W.-C., Feldens, P., Liebetrau, V., von Reumont, J., Hühnerbach, V., et al. (2015). The Eugen Seibold coral mounds offshore western Morocco: oceanographic and bathymetric boundary conditions of a newly discovered cold-water coral province. GeoMarine Lett. 35, 257-269. doi:10.1007/s00367-015-0405-7.

Goren, L., Idan, T., Shefer, S., and Ilan, M. (2021). Macrofauna Inhabiting Massive Demosponges From Shallow and Mesophotic Habitats Along the Israeli Mediterranean Coast. Front. Mar. Sci. 7, 612779. doi:10.3389/fmars.2020.612779.

Greene, H. G., Yoklavich, M. M., Starr, R. M., O’Connell, V. M., Wakefield, W. W., Sullivan, D. E., et al. (1999). A classification scheme for deep seafloor habitats. Oceanol. Acta 22, 663678. doi:10.1016/S0399-1784(00)88957-4. 


\section{Running Title}

Grigg, R., Grossman, E., Earle, S., Gittings, S., Lott, D., and McDonough, J. (2002). Drowned reefs and antecedent karst topography, Au'au Channel, S.E. Hawaiian Islands. Coral Reefs 21, 7382. doi:10.1007/s00338-001-0203-8.

Haroon, A., Micallef, A., Jegen, M., Schwalenberg, K., Karstens, J., Berndt, C., et al. (2021). Electrical Resistivity Anomalies Offshore a Carbonate Coastline: Evidence for Freshened Groundwater? Geophys. Res. Lett. 48. doi:10.1029/2020GL091909.

Hebbeln, D., Bender, M., Gaide, S., Titschack, J., Vandorpe, T., Van Rooij, D., et al. (2019). Thousands of cold-water coral mounds along the Moroccan Atlantic continental margin: Distribution and morphometry. Mar. Geol. 411, 51-61. doi:10.1016/j.margeo.2019.02.001.

Hebbeln, D., Wienberg, C., Wintersteller, P., Freiwald, A., Becker, M., Beuck, L., et al. (2014). Environmental forcing of the Campeche cold-water coral province, southern Gulf of Mexico. Biogeosciences 11, 1799-1815. doi:10.5194/bg-11-1799-2014.

Henriet, J. P., Hamoumi, N., Silva, A. C. Da, Foubert, A., Lauridsen, B. W., Rüggeberg, A., et al. (2014). Carbonate mounds: From paradox to World Heritage. Mar. Geol. 352, 89-110. doi:10.1016/j.margeo.2014.01.008.

Hovland, M., Croker, P. F., and Martin, M. (1994). Fault-associated seabed mounds (carbonate knolls?) off western Ireland and north-west Australia. Mar. Pet. Geol. 11, 232-246. doi:10.1016/0264-8172(94)90099-X.

Hovland, M., and Risk, M. (2003). Do Norwegian deep-water coral reefs rely on seeping fluids? Mar. Geol. 198, 83-96. doi:10.1016/S0025-3227(03)00096-3.

Illies, J. . (1980). "Form and function of graben structures: The Maltese Islands," in Mobile Earth: International Geodynamics Project Final Report of the Federal Republic of Germany, eds. H. Closs and et al. (Boldt: Boppard), 161-184.

Ingrosso, G., Abbiati, M., Badalamenti, F., Bavestrello, G., Belmonte, G., Cannas, R., et al. (2018). Mediterranean Bioconstructions Along the Italian Coast. Adv. Mar. Biol. 78, 61-136. doi:10.1016/bs.amb.2018.05.001.

James, N. P., Feary, D. A., Betzler, C., Bone, Y., Holbourn, A. E., Li, Q. Y., et al. (2004). Origin of late pleistocene bryozoan reef mounds; Great Australian Bight. J. Sediment. Res. 74, 2048. doi:10.1306/062303740020.

Knee, K. L., Crook, E. D., Hench, J. L., Leichter, J. J., and Paytan, A. (2016). Assessment of Submarine Groundwater Discharge (SGD) as a Source of Dissolved Radium and Nutrients to Moorea (French Polynesia) Coastal Waters. Estuaries and Coasts 39, 1651-1668. doi:10.1007/s 12237-016-0108-y.

Lambeck, K., Antonioli, F., Anzidei, M., Ferranti, L., Leoni, G., Scicchitano, G., et al. (2011). sealevel change along the Italian coast during the Holocene and projections for the future. Quat. Int. 232, 250-257. doi:10.1016/j.quaint.2010.04.026.

Lim, M., Rosser, N. J., Allison, R. J., and Petley, D. N. (2010). Erosional processes in the hard rock coastal cliffs at Staithes, North Yorkshire. Geomorphology 114, 12-21. doi:10.1016/j.geomorph.2009.02.011.

Lo Iacono, C., Gràcia, E., Diez, S., Bozzano, G., Moreno, X., Dañobeitia, J., et al. (2008). Seafloor characterization and backscatter variability of the Almería Margin (Alboran Sea, SW 
Mediterranean) based on high-resolution acoustic data. Mar. Geol. 250, 1-18. doi:10.1016/j.margeo.2007.11.004.

Locker, S. D., Reed, J. K., Farrington, S., Harter, S., Hine, A. C., and Dunn, S. (2016). Geology and biology of the "Sticky Grounds", shelf-margin carbonate mounds, and mesophotic ecosystem in the eastern Gulf of Mexico. Cont. Shelf Res. 125, 71-87. doi:10.1016/j.csr.2016.06.015.

Matos, L., Wienberg, C., Titschack, J., Schmiedl, G., Frank, N., Abrantes, F., et al. (2017). Coral mound development at the Campeche cold-water coral province, southern Gulf of Mexico: Implications of Antarctic Intermediate Water increased influence during interglacials. Mar. Geol. 392, 53-65. doi:10.1016/j.margeo.2017.08.012.

Micallef, A., Berndt, C., and Debono, G. (2011). Fluid flow systems of the Malta Plateau, Central Mediterranean Sea. Mar. Geol. 284, 74-85. doi:10.1016/j.margeo.2011.03.009.

Micallef, A., Camerlenghi, A., Georgiopoulou, A., Garcia-Castellanos, D., Gutscher, M.-A., Lo Iacono, C., et al. (2019). Geomorphic evolution of the Malta Escarpment and implications for the Messinian evaporative drawdown in the eastern Mediterranean Sea. Geomorphology 327, 264-283. doi:10.1016/j.geomorph.2018.11.012.

Micallef, A., Georgiopoulou, A., Bas, T. Le, Mountjoy, J. J., Huvenne, V. A. I., and Iacono, C. Lo (2013). Processes on the precipice: seafloor dynamics across the upper Malta-Sicily escarpment. in Rapport Commission Internationale Mer Méditerranée (Commission Internationale pour l'Exploration Scientifique de la Mer Mediterranee), 39-40.

Mienis, F., de Stigter, H. C., White, M., Duineveld, G., de Haas, H., and van Weering, T. C. E. (2007). Hydrodynamic controls on cold-water coral growth and carbonate-mound development at the SW and SE Rockall Trough Margin, NE Atlantic Ocean. Deep Sea Res. Part I Oceanogr. Res. Pap. 54, 1655-1674. doi:10.1016/j.dsr.2007.05.013.

Miller, K. G., Browning, J. V., Schmelz, W. J., Kopp, R. E., Mountain, G. S., and Wright, J. D. (2020). Cenozoic sea-level and cryospheric evolution from deep-sea geochemical and continental margin records. Sci. Adv. 6, eaaz1346. doi:10.1126/sciadv.aaz1346.

Pedley, M. H., House, M. R., and Waugh, B. (1976). The geology of Malta and Gozo. Proc. Geol. Assoc. 87, 325-341. doi:10.1016/S0016-7878(76)80005-3.

Ramos, A., Sanz, J. L., Ramil, F., Agudo, L. M., and Presas-Navarro, C. (2017). "The Giant ColdWater Coral Mounds Barrier Off Mauritania," in Deep-Sea Ecosystems Off Mauritania, eds. A. Ramos, F. Ramil, and J. Sanz (Dordrecht: Springer Netherlands), 481-525. doi:10.1007/978-94-024-1023-5_13.

Reijmer, J. J. G. (2021). Marine carbonate factories: Review and update. Sedimentology 68, 17291796. doi:10.1111/sed.12878.

Remia, A., and Taviani, M. (2005). Shallow-buried Pleistocene Madrepora-dominated coral mounds on a muddy continental slope, Tuscan Archipelago, NE Tyrrhenian Sea. Facies 50, 419-425. doi:10.1007/s10347-004-0029-2.

Riding, R. (2002). Structure and composition of organic reefs and carbonate mud mounds: concepts and categories. Earth-Science Rev. 58, 163-231. doi:10.1016/S0012-8252(01)00089-7.

Rüggeberg, A., Dullo, C., Dorschel, B., and Hebbeln, D. (2007). Environmental changes and 


\section{Running Title}

growth history of a cold-water carbonate mound (Propeller Mound, Porcupine Seabight). Int. J. Earth Sci. 96, 57-72. doi:10.1007/s00531-005-0504-1.

Savini, A., Malinverno, E., Etiope, G., Tessarolo, C., and Corselli, C. (2009). Shallow seep-related seafloor features along the Malta plateau (Sicily channel - Mediterranean Sea): Morphologies and geo-environmental control of their distribution. Mar. Pet. Geol. 26, 1831-1848. doi:10.1016/j.marpetgeo.2009.04.003.

Savini, A., Vertino, A., Marchese, F., Beuck, L., and Freiwald, A. (2014). Mapping Cold-Water Coral Habitats at Different Scales within the Northern Ionian Sea (Central Mediterranean): An Assessment of Coral Coverage and Associated Vulnerability. PLoS One 9, e87108. doi:10.1371/journal.pone.0087108.

Sustainable Energy and Water Conservation Unit (2015). The 2 nd Water Catchment Management Plan for the Malta Water Catchment District 2015 - 2021. Valleta.

Taviani, M., Angeletti, L., Ceregato, A., Foglini, F., Froglia, C., and Trincardi, F. (2013). The Gela Basin pockmark field in the strait of Sicily (Mediterranean Sea): chemosymbiotic faunal and carbonate signatures of postglacial to modern cold seepage. Biogeosciences 10, 4653-4671. doi:10.5194/bg-10-4653-2013.

Taviani, M., Freiwald, A., and Zibrowius, H. (2005). "Deep coral growth in the Mediterranean Sea: an overview," in Cold-Water Corals and Ecosystems, eds. A. Freiwald and J. M. Roberts (Berlin/Heidelberg: Springer-Verlag), 137-156. doi:10.1007/3-540-27673-4_7.

Violante, C., De Lauro, M., and Esposito, E. (2020). "Fine-scale seabed habitats off Capri Island, southern Italy," in Seafloor Geomorphology as Benthic Habitat, eds. P. T. Harris and E. Baker (Elsevier), 439-450. doi:10.1016/B978-0-12-814960-7.00024-5.

Webster, J. M., Clague, D. A., Riker-Coleman, K., Gallup, C., Braga, J. C., Potts, D., et al. (2004). Drowning of the -150 m reef off Hawaii: A casualty of global meltwater pulse 1A? Geology 32, 249. doi:10.1130/G20170.1.

Wheeler, A. J., Beyer, A., Freiwald, A., de Haas, H., Huvenne, V. a. I., Kozachenko, M., et al. (2007). Morphology and environment of cold-water coral carbonate mounds on the NW European margin. Int. J. Earth Sci. 96, 37-56. doi:10.1007/s00531-006-0130-6.

White, M. (2007). Benthic dynamics at the carbonate mound regions of the Porcupine Sea Bight continental margin. Int. J. Earth Sci. 96, 1-9. doi:10.1007/s00531-006-0099-1.

White, M., and Dorschel, B. (2010). The importance of the permanent thermocline to the cold water coral carbonate mound distribution in the NE Atlantic. Earth Planet. Sci. Lett. 296, 395-402. doi:10.1016/j.eps1.2010.05.025.

Wienberg, C., Titschack, J., Freiwald, A., Frank, N., Lundälv, T., Taviani, M., et al. (2018). The giant Mauritanian cold-water coral mound province: Oxygen control on coral mound formation. Quat. Sci. Rev. 185, 135-152. doi:10.1016/j.quascirev.2018.02.012.

Wood, R. (2001). Are reefs and mud mounds really so different? Sediment. Geol. 145, 161-171. doi:10.1016/S0037-0738(01)00146-4. 
Research conceptualization and principle writing was done by Aaron Micallef (AM) and Or M. Bialik (OMB), Ruth Duran Gallego (RDG), Timothy Le Bas (TLB) and Adam Gauci (AG) also took part in field work and data collection. Data processing was done by OMB, RDG, TLB and Andrea Giulia Varzi. Additional input was provided by Alessandra Savini. AM, OMB and RDG provided funding for this work. 